(2)

\title{
The Influence of Jigsaw Type Cooperative Models on Communication Skills of Elementary School Students
}

\author{
Dini Maielfi ${ }^{*}$, Sisri Wahyuni ${ }^{1}$ \\ ${ }^{1}$ Program Studi PGSD, STKIP ADZKIA, Padang, Indonesia.
}

DOI: 10.29303 /jppipa.v6i2.431

\section{Article Info}

Received : May 30th, 2020

Revised : June 29th, 2020

Accepted: July 4th, 2020

\begin{abstract}
This research is motivated by the low student communication skills caused by 1) when learning, students have not been able to convey their ideas either when discussing with friends, presentations, or when solving problems in learning; 2) students are shy to ask questions, tend to be silent, and when learning takes place the attention of students is not focused on learning or the other person; 3 ) students who are less academic yet able to convey the essence of learning if asked to become a tutor. This study aims to determine the impact of jigsaw on the communication skills of fourth-grade students at SDN 22 Kuranji Padang. This type of research is Pre-Experimental Design. The results of this study were obtained $\mu_{1}<\mu_{2},(67.66<82.05)$, with a significance of $N-$ Gain 0.45 in the medium category. Then Ha is accepted. From the results of this study, it was proven that jigsaw had a significant impact on the communication skills of fourth-grade students of SDN 22 Kuranji, Padang city.
\end{abstract}

Keywords: Cooperative; Jigsaw; Communication Skills.

Citation: Maielfi, D., \& Wahyuni, S. (2020). The Influence of Jigsaw Type Cooperative Models on Communication Skills of Elementary School Students. Jurnal Penelitian Pendidikan IPA (JPPIPA), 6(2), 205-209. doi: https://doi.org/10.29303/jppipa.v6i2.431

\section{Introduction}

Communication is very related in the teaching and learning process because the teaching and learning process can run through the communication process, whether it is communication within oneself such as using the mind, using memories, responding, and communicating with others, namely by conveying news to others, listening and respect the ideas of others. (Marfuah, 2017). So, the ability to communicate is one of the things that gives effect to learning because it can direct students to convey thoughts, share ideas with teachers and friends, when learning and when discussing working with friends.

Based on the results of observations made at SDN 22 Kuranji Padang, several problems were found in class IV SDN 22 Kuranji Padang, namely: 1) When teaching and learning took place, students did not dare to convey their knowledge ideas either when working in groups with friends, presentations, or when completing assignments that were given the teacher; 2 ) students are shy to ask questions, students tend to be more passive and only listen to information from the teacher, and when learning takes place students' attention is not focused on learning or the other person; 3) students who have low intellectual role play less in delivering learning material and have not been able to play an expert role.

Efforts to improve learning are carried out by applying learning models with the aim that the learning process is more directed and measurable. Suitable alternative learning models are cooperative learning models (Rumansyah, et al., 2016). Cooperative learning is a learning model that directs students to move and work together in teams and have a rule. Students are directed to discuss learning material together in teams with different learning abilities, races, and genders to learn the problems in the learning provided. (Fahruddin, et al., 2016). 
The Cooperative Model is expected to provide solutions in improving communication skills problems through the use of a Jigsaw cooperative learning model. This model can motivate students to play a greater role in learning and carry out greater obligations and have confidence in the ability to learn. The Jigsaw type cooperative model encourages and facilitates students to convey ideas of mind, knowledge, have tolerance, and carry the obligation to make the group successful. Students are encouraged and facilitated to convey their ideas to digest or describe the knowledge and experience gained and can encourage communication skills among students, carry out the task of achieving the group's success, achieving mastery in learning, and can share knowledge with other teams (Rusman, 2012).

The study of the problem of this research is "How is the Effect of Jigsaw Cooperative Model on Communication Skills in Integrated Thematic Learning of Class IV SDN 22 Kuranji Padang Students? The purpose of this study is to determine the effect of the Jigsaw Cooperative Model on Communication Skills in Integrated Thematic Learning of Class IV SDN 22 Kuranji Padang Students.

This type of Jigsaw cooperative learning is a group learning model with the procedure of students conducting learning activities through discussions with small groups with a combination of four or six different or different people, students help each other in learning and have their respective task obligations ". Jigsaw type cooperative model is a cooperative learning model that focuses on the task of student teams in small teams. (Rusman, 2012). Jigsaw type cooperative learning model is one of the cooperative learning models that divide students into heterogeneous groups of 4-6 people with the ability between one group relatively homogeneous to help each other and master the subject matter in expert groups so that it can help the group to achieve the results maximum (Doyan, et al., 2017).

The advantages of the Jigsaw cooperative model are: 1) giving students opportunities to discuss with other students, 2) students can understand the lessons discussed, 3) All team members of the students have the opportunity to act as experts in their teams, 4) when learning students cooperate with each other in terms of good or positive, 5) each student is complementary between one student with other students. (Majid, 2014) The steps of the cooperative model implemented in learning consist of: 1) reading references, 2) expert team collaboration, 3) Team discussion notes, 4) tests, 5) Team awards (Slavin, 2016).

Skills are the expertise possessed and obtained from counseling and completing tasks. The word communication comes from the Latin "Communist" which means to create togetherness or develop togetherness between two or more people.
Communication also comes from the word "Communico" which means to divide. "Communication is the process of channeling information from one person to another to influence the behavior of others" (Cangara, 2018). Furthermore, Communication is a stage of delivering messages, ideas, emotions, abilities, and others by using symbols in the form of words, design, numbers, and others (Budi, 2010).

Communication consists of two kinds, namely verbal and written communication or verbal and nonverbal communication (communication with sign codes). Oral skills (oral communication) is the ability to speak so that they can convey ideas in detail to the listener. Writing communication skills, namely writing competence correctly written for various readers. Nonverbal communication skills, namely the ability to express the expression of ideas using gestures, coding, facial expressions, tone of voice (Wahyuni, et al., 2019).

Communication skills are the ability of a person to deliver information to the recipient of information. Furthermore, according to Nevizond Chatab communication skills are the ability to bond through communication channels, so that information is clear and can be understood. These skills are not obtained from birth and do not come directly, skills are obtained through learning and doing training (Cangara, 2018).

Communication skills are very useful in the world of education and can build knowledge of the concept of learning. This skill is used so that students can express questions, express ideas, conduct discussions, make friends, and understand society (Noviyanti, 2011). In this study the authors limit research to aspects of oral communication skills, which the authors observe based on indicators, namely: 1) Deliver information and ideas to individuals or groups; 2) Give attention when others speak; 3) provide responses (Putri, et al., 2015).

\section{Method}

This type of research is Pre-Experimental Design, with the type of design used is One-Group PretestPosttest Design. This design can be described as follows (Sugiyono, 2012):

$$
\begin{array}{|lll|}
\hline \mathrm{O}_{1} & \mathrm{X} & \mathrm{O}_{2} \\
\hline
\end{array}
$$

Where:

$0_{1}=$ Pretest

$\mathrm{X}=$ treatment

$0_{2}=$ Posttest

Table 1. One-Group Pretest Posttest Design research design

\begin{tabular}{lllc}
\hline Group & Pretest & Treatment & Posttest \\
\hline Experiment & $\mathrm{O}_{1}$ & $\mathrm{X}$ & $\mathrm{O}_{2}$ \\
\hline
\end{tabular}


The subjects of this study were the fourth-grade students of SDN 22 Kuranji Padang in the odd semester of the 2019/2020 school year, amounting to 21 people, 10 male students, and 11 female students. The research instruments to be used are the Learning Implementation lesson Plan and the Performance Assessment instrument with a Rating Scale model. The instrument being tested must comply with the validity and reliability requirements.

For the instrument to meet the criteria, validation needs to be done by the validator/expert. Instrument analysis includes testing the validity and reliability of the instrument. After evaluating by the validator, the data is analyzed, then the data is made in the form of a percentage, then conducted a hypothesis test, with the formulation of the proposed hypothesis is:

Where:

$$
\begin{aligned}
& H_{1}: \mu_{1}<\mu_{2} \\
& H_{0}: \mu_{1}>\mu_{2}
\end{aligned}
$$

$\mu_{1}=$ Average pretest of student communication skills.

$\mu_{2}=$ Average posttest of student communication skills.

The test criteria are: Accept $\mathrm{H}_{0}$ if $\mu 1>\mu 2$, reject $\mathrm{H}_{0}$ if $\mu 1<\mu 2$ with the following information:

$$
\begin{array}{ll}
\mathrm{H}_{0}: \quad \mu_{1} \geq \mu_{2} \quad \begin{array}{l}
\text { The average pretest on students' } \\
\text { communication skills is the same as } \\
\text { the average posttest. }
\end{array} \\
\mathrm{H}_{1}: \quad \mu_{1}<\mu_{2} \begin{array}{l}
\text { The average pretest on students' } \\
\text { communication skills is smaller } \\
\text { than the average posttest. }
\end{array}
\end{array}
$$

To test this hypothesis the N-Gain Score formula is used:

$$
N \text { Gain }=\frac{\text { Skor Posttest }- \text { Skor Pretest }}{\text { Skor ideal }- \text { Skor Pretest }}
$$

Criteria for N Gain Score, (Nashiroh, et.al., 2020), namely:

Table 2. N-Gain Values Criteria Score

\begin{tabular}{ll}
\hline $\mathbf{N}$-Gain Value & Criteria \\
\hline Gain $>0.7$ & High \\
$0.7 \geq$ gain $\geq 0.3$ & Medium \\
gain $<0.3$ & Low \\
\hline
\end{tabular}

\section{Result and Discussion}

\section{a. Student Initial Test Data}

When researching, observers observe students 'skills from the beginning of the teaching and learning process taking place, observers observe students' communication skills using observation sheets. Pretest data were obtained from the beginning of the teaching and learning process and before being given treatment. The researcher conducted 3 pretests for 3 meetings or 3 lessons.

Table 3. Student Pretest Result Data

\begin{tabular}{llll}
\hline & $\begin{array}{l}\text { Meeting 1 } \\
\text { Pt1 }\end{array}$ & $\begin{array}{l}\text { Meeting 2 } \\
\text { Pt2 }\end{array}$ & $\begin{array}{l}\text { Meeting 3 } \\
\text { Pt3 }\end{array}$ \\
\hline $\mathrm{N}$ & 21.00 & 21.00 & 21.00 \\
N-Maximum & 100.00 & 100.00 & 93.75 \\
N-Minimum & 56.25 & 37.5 & 43.75 \\
Total Score & 1600.00 & 1350.00 & 1312.50 \\
$\begin{array}{l}\text { Average } \\
\begin{array}{l}\text { Average of } 3 \\
\text { meetings }\end{array}\end{array}$ & 76.19 & 64.29 & 62.5 \\
\hline
\end{tabular}

\section{b. Student Posttest Data}

Just like pretest data, posttest data is obtained during learning, after students are given a pretest or after students' communication skills are observed, then students are given treatment. The researcher conducted 3 posttests for 3 meetings or 3 lessons and just like pretest, posttest was also done 3 times.

Table 4. Student Posttest Results Data

\begin{tabular}{llll}
\hline & $\begin{array}{l}\text { Meeting 1 } \\
\text { Pt1 }\end{array}$ & $\begin{array}{l}\text { Meeting 2 } \\
\text { Pt2 }\end{array}$ & $\begin{array}{l}\text { Meeting 3 } \\
\text { Pt3 }\end{array}$ \\
\hline $\mathrm{N}$ & 21.00 & 21.00 & 21.00 \\
N-Maximum & 100.00 & 100.00 & 100.00 \\
N-Minimum & 56.25 & 56.25 & 62.5 \\
Total Score & 1600.00 & 1713.00 & 1794.00 \\
$\begin{array}{l}\text { Average } \\
\text { Average of 3 } \\
\text { meetings }\end{array}$ & $79, .19$ & 81.55 & 85.42 \\
\hline
\end{tabular}

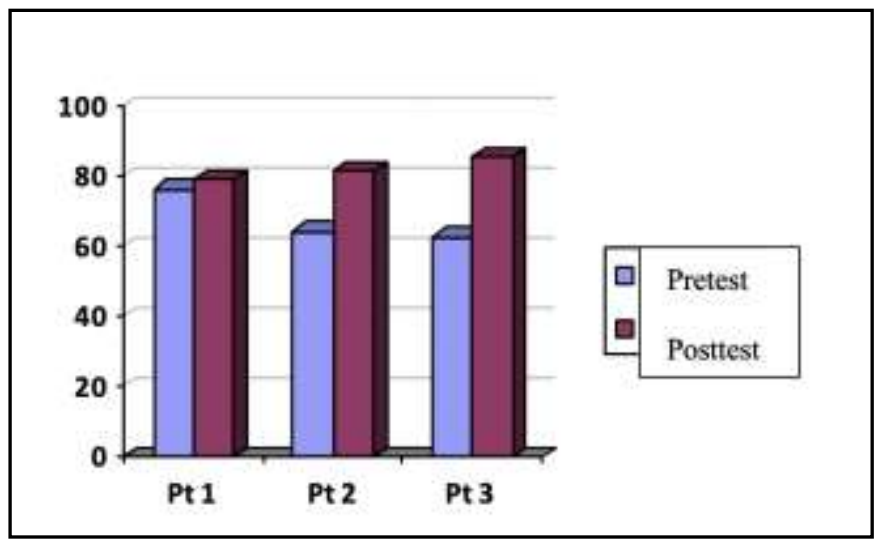

Figure 1. Comparison Diagram of the Average Pretest and Posttest Value of Student Communication Skills

Hypothesis testing is done by using the Gain Score formula, before calculating the Gain Score formula, first look for the average pretest and posttest then enter it into the N-Gain Score formula, found below.

$$
N \text { Gain }=\frac{\text { Skor Posttest }- \text { Skor Pretest }}{\text { Skor ideal }- \text { Skor Pretest }}
$$




$$
\begin{aligned}
& N \text { Gain }=\frac{82,05-67,66}{100-67,66} \\
& N \text { Gain }=\frac{14,39}{32,34} \\
& N \text { Gain }=0,45
\end{aligned}
$$

From the results of the hypothesis test, the gain score is 0.45 with the medium category. In a sense, students' communication skills are better by using a jigsaw cooperative learning model, because when using a jigsaw model each student has his obligation to understand the learning theme, according to the jigsaw stage the 3 students discuss with an expert group, at the time of discussion with expert groups students better understand the topic or material, and after the expert group, discussion students do a team report, at the time of the team report each student is tasked with teaching other students in the original group about the material obtained. And at the time of the team report, all students convey the information he got from the expert group, thus making students have to express opinions and information obtained from the expert group, with students working in groups making students more motivated to learn, and students who lack academic ability will be helped by students who have the high academic ability and group responsibilities are worked on together.

By the expert opinion about the definition of a jigsaw cooperative model that is a cooperative learning model that focuses on the task of student teams in small teams. Cooperative learning jigsaw model is a group learning model with the procedure of students doing learning activities through discussion with small groups with a combination of four or six different or different people, students help each other in learning and have their respective task obligations (Rusman, 2012).

Based on the data processing obtained, it is seen that there is an influence on students' communication skills using a Jigsaw cooperative model. This can be seen from the average value of the pretest and the average value of the posttest on the communication skills observation sheet, where the average value of the posttest is higher than the average value of the pretest. This difference can be seen through hypothesis testing using the N-Gain Score test. The researcher concludes that reject $\mathrm{H}_{0}$ and accept $\mathrm{H}_{l}$, in other words, the average posttest on communication skills of students is greater than the pretest average because at the time of the pretest or when observing communication skills at the beginning of learning the researcher does not apply the model, whereas, at the time of the posttest or when observing students' communication skills in the middle of learning, researchers teach using this model.
The results of this study are in line with research conducted at SMP Negeri 3 Natar South Lampung, it was found that in the experimental class the average competence in oral communication had a good category (81.48). Student learning outcomes increase, with an average gain (0.57). Most students $(96.30 \%)$ have good comments on the use of Jigsaw cooperative learning models. Thus, Jigsaw type learning models have an impact on improving oral communication competence and learning outcomes (Mila et al., 2014). Then Based on research conducted at Abant Izzet Baysal University in the experimental group obtained an average of 38.58, and in the control group, the average was 28.85. Thus, it can be seen that the average experimental group is much higher than the control group. The results show that there are statistically significant differences between the experimental and control groups (Evcim et al., 2013).

Then in the activities of medical students in interviewing LTPAC personnel about their role, the results of knowledge tests showed that the ability of students to understand the role of LTPAC personnel in general obtained the lowest score of 3.65 and the highest 4.12 with an average of 3.91, thus the use of jigsaw well received by the participants and effective for introducing medical students to the nursing home environment. (Buhr, et al, 2014).

With the use of this model, some students can express their ideas, express information, and respond to students better, when asked good questions from friends, teachers (researchers) more than some students can respond. And when discussing students more enthusiastic, compact, each student can express their ideas in groups, exchange ideas, work well, and with good time management, both in the sense that students can complete group assignments on time. This is in line with the strengths of the Jigsaw type cooperative model, namely: 1) providing opportunities for students to discuss with other students, 2) students can understand the lessons discussed, 3) All team members of students have the opportunity to act as experts in their teams, 4) when students learn to cooperate in a good or positive way, 5) each student completes each other between one student and other students (Majid, 2014).

\section{Conclusion}

Based on the results of research and data processing, the average pretest on student communication skills is small than the average posttest on student communication skills, and it can be concluded that students' communication skills are better by using a Jigsaw cooperative model. With the average obtained at the pretest is 67.66, while the average obtained at the posttest is 82.05 . Hypothesis test results 
obtained are $\mu_{1}<\mu_{2}$, meaning $\mathrm{H}_{1}$ is accepted $\mathrm{H}_{0}$ is rejected. So, the researcher can conclude that the use of a Jigsaw cooperative model has a significant influence on communication skills.

\section{Acknowledgments}

Thank you very much to the Chairperson of STKIP Adzkia, Chair of the Elementary School Teacher Education Study Program, fellow lecturers, research colleagues who have agreed to collaborate in completing this research so that it can be resolved properly.

\section{References}

Budi, R. (2010). Pengantar Pengantar Ilmu Komunikasi 106 hal (I). Makassar: KRETAKUPA Print.

Buhr, G. T., Heflin, M.T., White, H. K., \& Pinheiro, S.O. (2014). Using the Jigsaw cooperative learning method to teach medical students about long-term and postacute care. Journal of the American Medical Directors Association, 15(6), 429-434. https://doi.org/10.1016/i.jamda.2014.01.015

Cangara, H. (2018). Pengantar Ilmu Komunikasi. Jakarta: Raja Grafindo Persada.

Doyan, A., Gunada, W.S., \& Adriani, I.A.D. (2017). Perbedaan Pengaruh Model Pembelajaran Kooperatif Tipe Stad Dan Tipe Jigsaw Terhadap Hasil Belajar Fisika Ditinjau Dari Motivasi Belajar Siswa. Jurnal Penelitian Pendidikan IPA, 1(1), 1-13. https://doi.org/10.29303/ippipa.v1i1.1

Evcim, H., \& İpek, Ö.F. (2013). Effects of Jigsaw II on Academic Achievement in English Prep Classes. Procedia - Social and Behavioral Sciences, 70, 16511659. https://doi.org/10.1016/j.sbspro.2013.01.236

Fahruddin, A. Wahab Jufri, \& Jamaluddin. (2016). Pengaruh Model Pembelajaran Kooperatif Terhadap Hasil Belajar Kognitif Ditinjau Dari Kemampuan Akademik Mahasiswa. Jurnal Penelitian Pendidikan IPA (JPPIPA), 2(1). https://doi.org/10.29303/jppipa.v2i1.27

Majid, A. (2014). Pendekatan Ilmiah Dalam Implementasi Kurikulum 2013. Bandung: Remaja Rosdakarya.

Marfuah. (2017). Meningkatkan Keterampilan Komunikasi Peserta Didik melalui Model Pembelajaran Kooperatif Tipe Jigsaw. Jurnal Pendidikan Ilmu Sosial, 26(2), 148-160. https://doi.org/http://dx.doi.org/10.17509/jpis. v26i2.8313

Mila, V., Jalmo, T., \& Marpuang, R. R. T. (2014). Pengaruh Model Pembelajaran Jigsaw Terhadap Kemampuan Komunikasi Lisan Dan Hasil Belajar Siswa. 1-17.

Nashiroh, P. K., Ekarini, F., \& Ristanto, R. D. (2020). Efektivitas Penerapan Model Pembelajaran
Kooperatif Tipe Jigsaw Berbatuan Mind Map terhadap Kemampuan Pedagogik Mahasiswa Mata Kuliah Pengembangan Program Diklat. Jurnal Pendidikan Teknologi Dan Kejuruan, 17(1), 43. https://doi.org/10.23887/jptkundiksha.v17i1.22906

Noviyanti, M. (2011). Prestasi Belajar Mahasiswa Pada Tutorial Online Berbasis. Jurnal Pendidikan, 12(02), 80-88.

Putri, D.W., Yennita., \& Nor, M. (2015). Kemampuan Berkomunikasi Siswa Melalui Penerapan Strategi Pembelajaran Berbasis Proyek Di Kelas XI SMA Babussalam Pekanbaru. Jurnal Online Mahasiswa (JOM) Bidang Keguruan dan Ilmu Pendidikan. 2(2). 11

Rumansyah, Kosim, \& Harry, S. (2016). Pengembangan Model Pembelajaran Kooperatif Tipe Kosaji Pada Pembelajaran Fisika. 2(2), 39-50. doi: https://doi.org/10.29303/jppipa.v2i2.42

Rusman. (2012). Model-model Pembelajaran Mengembangkan Profesionalisme Guru. Depok: Rajawali Pers.

Slavin, R. E. (2016). Cooperative Learning : Teori, Riset dan Praktik. Bandung: Nusa Media.

Sugiyono. (2012). Metode Penelitian Kuantitatif, Kualitatif dan RED. Bandung: Alfabeta.

Wahyuni, L. M., Suwintana, I. ketut, \& Sudiadnyani, I. O. (2019). Eksplorasi Keterampilan Komunikasi Yang Dibutuhkan Pasar Kerja Bidang Akuntansi. Jurnal Riset Terapan Akuntansi, 3(1), 22-30. doi. http://dx.doi.org/10.5281/zenodo.3837871 